\title{
FLUTUAÇÃO DAS PROTEÍNAS SÉRICAS EM VACAS PRIMÍPARAS E MULTÍPARAS NO PERÍODO PRÉ-PARTO
}

\author{
MACHADO NETO,R.; PRADO, G.V.B.; BESSI, R.; HATTNHER, F.L. \\ Departamento de Zoologia - ESALQ/USP - C.P. 9 - CEP: 13418-900 Piracicaba, SP
}

\begin{abstract}
RESUMO: O comportamento das proteínas séricas foi avaliado em dois grupos de vacas de leite, 6 primíparas e 6 multíparas, durante as últimas 6 semanas pré-parto. Para separação da fração protéica foi empregado o método de eletroforese, enquanto para quantificação da proteína total foi utilizado o método de biureto. 0 sangue, retirado da região coccígea, foi amostrado nos períodos $5,4,3,2,1$ semanas pré-parto e no dia do parto. Os resultados indicam uma queda na concentração da proteína total $(p<0.0001)$, em função do decréscimo da concentração de imunoglobulina (p $<0.0001$ ), durante o período analisado. A proteína total decresceu de $9,82+0,7 \mathrm{~g} / 100 \mathrm{ml}$, na quinta semana pré-parto, para $7,92+0,6 \mathrm{~g} / 100 \mathrm{ml}$ no dia do parto (valor mínimo médio registrado). No mesmo periodo, a imunoglobulina variou de $4,12+0,7 \mathrm{~g} / 100 \mathrm{ml}$ para $2,40+0,5 \mathrm{~g} / 100 \mathrm{ml}$ (valor mínimo médio registrado). Considerando-se os dois grupos de vacas separadamente, as multíparas mostraram uma tendência de decréscimo mais acentuado na concentração de imunoglobulina $(p<0.09)$ quando comparadas com as primíparas.
\end{abstract}

Descritores: imunidade passiva, colostro, vaca

\section{SERUM PROTEIN FLUCTUATION IN PRIMIPAROUS AND MULTIPAROUS COWS DURING THE PRE-PARTUM PERIOD}

\begin{abstract}
The fluctuation of serum protein was investigated in two groups of milk cows, 6 primiparous and 6 multiparous, during the last six weeks pre-partum. Electrophoresis and the biuret method were used to analyse the serum proteins. Blood was collected from the coccigeal region at 5, 4, 3, 2, 1 weeks pre-partum and at birth. The results indicate a decrease in the total protein concentration $(p<0.0001$ ) as a consequence of immunoglobulin concentration decrease $(p<0.0001)$ during the experimental period. The total protein decreased from $9.82+0.7$ $\mathrm{g} / 100 \mathrm{ml}$, six weeks pre-partum, to $7.92+0.6 \mathrm{~g} / 100 \mathrm{ml}$, at birth (minimum value registered). In the same period immunoglobulin decreased from $4.12+0.7 \mathrm{~g} / 100 \mathrm{ml}$ to $2.40+0.5 \mathrm{~g} / 100 \mathrm{mI}$ (minimum value registered). Considering the two groups of cows separately, the multiparous showed a tendency to decrease more the immunoglobulin concentration ( $p<0.09$ ), when compared to primiparous.
\end{abstract}

Key Wonds: passive immunity, colostrum, cow, Nelore

\section{INTRODUÇÃO}

Ao nascer, todo animal é considerado imaturo com relação ao sistema imunológico e, portanto, precisa receber anticorpos maternos para garantir sua sobrevivência. Em muitas espécies, incluindo os bovinos, o recém nascido recebe as imunoglobulinas maternas através da ingestão de colostro, o qual atuará como via de transferência de imunidade (BRAMBELL, 1958).

Em bovinos a formação do colostro acontece principalmente durante as quatro semanas que antecedem o parto, período no qual ocorre a migração das imunoglobulinas presentes na corrente sanguínea da mãe para a glândula mamária. O proces-so de transporte é seletivo, predominando a transferência de IgG e, mais espe- cificamente, IgG1. A passagem ocorre através das células alveolares e, aparentemente, está envolvida com a presença de receptores na membrana das mesmas (DIXON et al., 1961; LARSON et al., 1980; WATSON, 1980).

Em bovinos de leite, provavelmente em função da especialização, já foi mostrado que a migração de imunoglobulinas séricas para a glândula mamária, durante a formação do colostro, determina uma queda de concentração desta proteína na corrente sanguínea, nas últimas semanas pré-parto (LARSON \& KENDALL, 1957; LARSON \& HAYS, 1958; DIXON et al., 1961).

Por outro lado, no trabalho realizado com vacas Nelore, por MACHADO NETO \& d'ARCE (1979), este decréscimo na concentração de imunoglobulinas séricas não foi verificado. Os autores 
sugerem que este fato pode estar relacionado com característica de baixa produção de leite desta raça, que consequentemente estaria associada a uma menor atividade secretora da glândula mamária, demandando uma mobilização menor de anticorpos séricos para secreção láctea.

Uma outra fonte de variação com relação ao colostro diz respeito à experiência reprodutiva. Vacas primíparas geralmente produzem um colostro de qualidade inferior, tanto no que diz respeito a concentração quanto na variedade de anticorpos que ele veicula (KRUSE, 1970; OYENIYI \& HUNTER, 1978; MULLER \& ELLINGER, 1981, DONAVAN et al., 1986).

Tendo como base os aspectos relacionados, este trabalho foi desenvolvido com o objetivo de estudar comparativamente a flutuação de imunoglobulinas séricas em vacas de leite primíparas e multíparas.

\section{MATERIAL, E METODOS}

Foram utilizadas 12 vacas de leite, sendo 6 multíparas e 6 primíparas, nas quais foram realizadas coletas semanais de sangue a partir de 5 semanas antes do parto, com base na data prevista a partir da inseminação. O sangue, retirado da região coccígea, foi amostrado nos períodos 5,4 , $3,2,1$ semanas pré-parto e no dia do parto. O soro obtido por centrifugação e armazenado a $-20^{\circ} \mathrm{C}$, foi analisado pelos métodos de biureto para proteína total (REINHOLD, 1953) e eletroforese (BREWER \& ASHWORTH, 1969) para o fracionamento das proteínas séricas. Os géis revelados, com os fracionados séricos, foram lidos em densitômetro e os gráficos obtidos foram utilizados para quantificar a imunoglobulina sérica.

O delineamento estatístico foi inteiramente casualizado com parcelas subdivididas. Análises de variância e de regressão dos resultados, foram realizadas empregando-se o programa SAS-STAT.

\section{RESULTADOS E DISCUSSÃO}

Os resultados médios obtidos para os parâmetros proteína total e imunoglobulina estão apresentados na TABELA 1.

Os dois grupos de animais apresentaram queda significativa $(p<0.0001)$ da fração imunoglobulina durante o período estudado, o que acarretou um decréscimo significativo ( $\mathrm{p}<$ 0.0001 ) no nível de proteína total, condição também observada por LARSON \& KENDALL (1957), LARSON \& HAYS (1958) e DIXON et al. (1961). O decréscimo de Ig estimado para os dois grupos de vacas, através da equação linear obtida $(\mathrm{Y}=22,889-3,196 \mathrm{X})$, foi de $1,6 \mathrm{~g} / 100 \mathrm{ml}$ entre a data 5 semanas e o parto.

TABELA 1 - Concentrações médias $(\mathrm{g} / 100 \mathrm{ml}$ ) de proteína total (PT) e imunoglobulina (Ig) em vacas primíparas e multíparas nas últimas 5 semanas de gestação.

\begin{tabular}{|c|c|c|c|c|c|c|c|c|}
\hline $\mathrm{g} / 100 \mathrm{ml}$ & sem & arto & -5 & -4 & -3 & -2 & -1 & 0 \\
\hline \multirow{2}{*}{ Primíparas } & PT & \multicolumn{2}{|c|}{$10,24+0,4^{*}$} & $8,39+0,6$ & $7,64+1,0$ & $7,92+0,8$ & $7,54+0,8$ & $7,89+0,6$ \\
\hline & $\mathrm{Ig}$ & \multicolumn{2}{|c|}{$4,10+0,4$} & $3,59+0,5$ & $2,48+0,9$ & $2,63+0,8$ & $2,23+1,1$ & $2,45+0,4$ \\
\hline \multirow{2}{*}{ Multíparas } & PT & \multicolumn{2}{|c|}{$9,39+0,6$} & $8,94+0,3$ & $9,03+0,6$ & $9,0+0,7$ & $8,35+0,6$ & $7,96+0,6$ \\
\hline & $\mathrm{Ig}$ & \multicolumn{2}{|c|}{$4,13+0,6$} & $3,64+0,7$ & $3,55+0,7$ & $3,35+0,5$ & $2,91+0,5$ & $2,34+0,8$ \\
\hline \multirow{2}{*}{ Média } & PT & \multicolumn{2}{|c|}{$9,82+0,7$} & $8,77+0,7$ & $8,42+0,9$ & $8,46+1,0$ & $7,95+0,6$ & $7,92+0,6$ \\
\hline & $\operatorname{Ig}$ & \multicolumn{2}{|c|}{$4,12+0,7$} & $3,62+0,8$ & $3,02+0,9$ & $2,99+0,9$ & $2,57+0,7$ & $2,40+0,5$ \\
\hline
\end{tabular}

*+ Desvio Padrão 
Considerando-se os dois grupos de vacas separadamente, as multíparas mostraram uma tendência $(\mathrm{p}<0.09)$ de decréscimo mais acentuado de imunoglobulinas, quando comparadas com as primíparas. Uma queda menos acentuada de imunoglobulinas no grupo das vacas primíparas, poderia ser explicado por estas possuírem um menor número de células secretoras, apresentando, consequentemente, uma mobilização menor de anticorpos da corrente sanguínea para a glândula mamária.

\section{REFERENCIAS BIBLIOGRÁFICAS}

BRAMBELL, F.W.R. The passive immunity of the young mammal. Biology Review, Cambridge, v.33, p.488-531, 1958 .

BREWER, J.M.; ASHWORTH, R.B. Disc electrophoresis. Journal of Chemical Education, Easton, v.46, p.41-45. 1969.

DIXON, F.J.; WEIGLE, W.O.; VASQUEZ, J.J. Metabolism and mammary secrection of serum proteins in the cow. Laboratory Investigation, Baltimore, v.10, p.216-236, 1961.

DONOVAN, G.A.; BADINGA, L.; COLLIER, R.J.; WILCOX, C.J.; BRAUN, R.K. Factors influencing passive transfer in dairy calves. Joumal of Dairy Science, Lancaster, v.69, p.754-759, 1986.

KRUSE, V. Yield of colostrum and immunoglobulin in cattle at the first milking after parturation. Animal Production, Edinburgh, v.12, p.619-626, 1970.

LARSON, B.L.; KENDALL, K.A. Changes in specific blood serum protein levels associated with parturition in the bovine. Journal of Dairy Science, Lancaster, v.40, p.659-666, 1957.
LARSON, B.L.; HAYS, R.L. An explanation for bovine parturation edema and treatment with blood protein replacements. Joumal of Dairy Science, Lancaster, v.41, p.995-997, 1958.

LARSON, B.L.; HEARY JR., H.L.; DEVERY, J.E. Immunoglobulin production and transport by the mammary gland. Journal of Dairy Science, Lancaster, v.40, p.377-380, 1980.

MACHADO NETO, R.; d'ARCE, R.D. Proteínas séricas nos períodos pré e pós-parto de vacas da raça Nelore. Revista de Agricultura, Piracicaba, v.53, p.13-19, 1979.

MULLER, L.D.; ELLINGER, D.K. Colostral immunoglobulin concentration among breeds of dairy cattle. Journal of Dairy Science, Lancaster, v.64, p. 1727-1730, 1981.

OEYNIY1, O.O.; HUNTER, A.G. Colostral constituints including, immunoglobulins in the first three milkings postpartum. Journal of Dairy Science, Lancaster, v.61, p.44-48, 1978 .

REINOLD, J.G. Total protein, albumin and globulin. In: REINER, M. Standard methods of clinical chemistry. New York: Academic Press, 1953. p.1218.

SAS/STAT USERS GUIDE. Release 6.03 Edition. Cary, NC: SAS, 1988.

WATSON, D.L. Immunological functions of the mammary gland and its secretion: comparative Review. Australian Journal of Biology Science, Melbourne, v.33, p.403-422, 1980.

Entregue para publicação em 03.08.94

Aceito para publicação em 29.12.94 